\title{
Haji Oemar Said Tjokroaminoto: Biografi, Dakwah dan Kesejahteraan Sosial
}

\author{
Abdul Syukur \\ UIN Raden Intan Lampung \\ abdulsyukur@gmail.com \\ Robby Aditya Putra, \\ UIN Raden Intan Lampung \\ robbyadityaputra@gmail.com \\ Saifullah \\ UIN Raden Intan Lampung \\ saifullah@gmail.com \\ Dede Mercy Rolanda \\ UIN Raden Intan Lampung \\ dedemercy@gmail.com
}

\begin{abstract}
H.O.S Tjokroaminoto a da'wah figure who cannot be separated from the development of the Islamic Syarikat (SI) organization which later turned into the Islamic Sarikat Party (PSI) and the Indonesian Islamic Syarikat Party (PSII), da'wa and social welfare. Tjokroaminoto was the Chairman of the Islamic Society and was the leader of the PSI and PSII until the end of his life. Tjokroaminoto is the most influential figure in the history of the Islamic Syarikat. Therefore, this paper will discuss biographies and works, involvement in the Sarekat Islam and also the interpretation of the principles that Tjokroaminoto holds to deepen every social welfare-based da'wah movement. Raden Mas Haji Oemar Said Tjokroaminoto or known as H.O.S Tjokroaminoto is one of the national movement figures who exerts influence to fight for social welfare and also has a major influence on the dynamics of Indonesian politics, including shaping political thinking and influencing the political actions of many national movement figures.
\end{abstract}

Keyword: H.O.S Tjokroaminoto, da'wah, social welfare

\begin{abstract}
Abstrak
H.O.S Tjokroaminoto tokohdakwah yang tidak dapat dilepaskan dari perkembangan organisasi Syarikat Islam (SI) yang kemudian berubah menjadi Partai Sarikat Islam (PSI) dan Partai Syarikat Islam Indonesia (PSII) dan
\end{abstract}

Jurnal Dakwah dan Komunikasi

IAIN Curup-Bengkulu | E-ISSN : 2548-3366, P-ISSN:2548-3293 
hubungannya dengan dakwah dan kesejahteraan sosial. Tjokroaminoto merupakan Ketua Syarikat Islam dan menjadi pemimpin PSI dan PSII hingga akhir hayatnya. Tjokroaminoto merupakan tokoh yang paling berpengaruh dalam sejarah Syarikat Islam. Maka dari itu, Tulisan ini akan membahas mengenai biografi dan karya, keterlibatan dalam Sarekat Islam dan juga tafsir asas yang dipegang teguh oleh Tjokroaminoto untuk mendalami setiap pergerakan dakwah dan kesejahteraan sosial. Raden Mas Haji Oemar Said Tjokroaminoto atau dikenal dengan H.O.S Tjokroaminoto merupa- kan salah satu tokoh pergerakan nasional yang memberikan pengaruh untuk memperjuangkan kesejahteraansosial dan juga berpengaruh besar dalam dinamika politik Indonesia, termasuk di dalamnya membentuk pemikiran politik maupun mempengaruhi tindakan politik banyak tokoh pergerakan nasional.

Kata Kunci: H.O.S Tjokroaminoto, da'wah, Kesejahteraan Sosial

\section{Pendahuluan}

Raden Mas Haji Oemar Said Tjokroaminoto atau dikenal dengan H.O.S Tjokroaminoto merupa- kan salah satu tokoh pergerakan nasional yang memberikan pengaruh besar dalam dinamika politik Indonesia, termasuk di dalamnya membentuk pemikiran politik maupun mem- pengaruhi tindakan politik banyak tokoh pergerakan nasional. H.O.S. Tjokroaminoto terlahir dari keluarga ningrat dan sekaligus ketu- runan ulama, karena buyutnya adalah Kyai Bagoes Kesan Besari yang merupakan kyai ternama di daerah Ponorogo yang memperistri putri dari Susuhunan II. ${ }^{1}$ Latar belakang keluarga dan pendidikan yang dimiliki oleh Tjokroaminoto dengan demikian menunjukkan status sosial yang tinggi, selain juga latar belakang agama Islam yang relatif kuat melekat pada dirinya.

Tjokroaminoto merupakan guru politik sekaligus teman diskusi terhadap beberapa tokoh pergerakan nasional seperti Soekarno, Kartosoewiryo, Abikoesno, Alimin dan Muso. Bahkan, Soekarno yang dikemudian hari menjadi Presiden Republik Indonesia pertama, pernah menjadi menantu dari Tjokroaminoto, walaupun pernikahan tersebut diakui oleh Soekarno sebagai bentuk penghormatan dan rasa kasihan terhadap Tjokroaminoto sehingga pernikahannya dengan Oetari - putri Tjokroaminoto - hanyalah berupa kawin gantung. ${ }^{2}$ Menarik- nya, beberapa murid Tjokroaminoto memiliki pandangan

1 Anhar Gonggong, H.O.S. Tjokroaminoto (Jakarta: Departemen Pendidikan dan Kebudayaan, 1985), 7.

2 Cindy Adams,Bung Karno, Penyambung Lidah Rakyat Indonesia. (Jakarta: Gunung Agung, 1966), 38. 
politik yang berbeda dalam perkem- bangan pemikiran politik serta ideologi politik yang dianutnya.

H.O.S Tjokroaminoto juga merupakan tokoh yang tidak dapat dilepaskan dari per- kembangan organisasi Syarikat Islam (SI) yang kemudian berubah menjadi Partai Sarikat Islam (PSI) dan Partai Syarikat Islam Indonesia (PSII). Tjokroaminoto merupakan Ketua Syarikat Islam dan menjadi pemimpin PSI dan PSII hingga akhir hayatnya. Tjokroaminoto merupakan tokoh yang paling berpengaruh dalam sejarah Syarikat Islam. ${ }^{3}$

Maka dari itu, Tulisan ini akan membahas mengenai biografi dan karya, keterlibatan dalam Sarekat Islam dan juga tafsir asas yang dipegang teguh oleh Tjokroaminoto untuk mendalami setiap pergerakan dakwah H.O.S Tjokromaninoto.

\section{Hasil dan Pembahasan}

Raden Oemar Said Tjokroaminoto yang dikenal dengan nama H.O.S.Tjokroaminoto lahir di Ponorogo, 16 Agustus 1883. Di dalam tubuh Tjokroaminoto mengalir darah kyai dan priyayi, bangsawan budi dan bangsawan darah sekaligus. Karenanya, dalam perkembangan jalan hidupnya di kemudian hari kedua unsur tadi sangat mempengaruhinya. Kakeknya RM.adipati Tjokronegoro yang merupakan seorang Bupati di Penorogo, Jawa Timur. Sedangkan ayahnya, Raden Mas Tjokromiseno adalah Wedana Distrik Kleco, Madiun. Tjokroaminoto secara formal berpendidikan secara formal sekolah dengan system pendidikan barat. Maka, ia mampu menguasai bahasa belanda dan inggris. ${ }^{4}$

Pendidikan dasar ditempuhnya di Madiun, di sekolah Belanda. Sedangkan pendidikan lanjut ditempuhnya di Opleiding School Voor Inlandsche Ambtenaren (OSVIA) yang merupakan sekolah untuk pegawai pribumi, di Magelang, Jawa Tengah, tamat pada tahun 1902. Di OSVIA yang lama pendidikannya selama 5 tahun itu pengantarnya bahasa Belanda.

Lulus dari OSVIA, eslama 3 tahun 1902-1905, Tjokro menjadi juru tulis patih di Ngawi, Jawa Timur, lalu menjadi patih , menjadi pejabat dilingkungan pegawai negeri. Jadi pegawai negeri ia hanya betah selama 3 tahun lalu berhenti, tak lama setelah ia menikah dengan Suharsikin, putrid dari Patih Ponorogo, tahun 1905. Alasannya Tjokro merasa cocok dengan pekerjaan pegawai negeri di zaman penjajahan yang terus menerus merendah dihadapan atasannya yang orang Belanda. Lalu ia pindah ke Surabaya dan berkerja di perusahaan swasta.

Sambil bekerja, Tjokro masih mneyempatkan diri mengikuti sekolah lanjutan di sore hari, Burgerlijke Avond School. Selain sebagai pegawai swasta, rumah Tjokro juga menerika kos-kosan yang dikelola istrinya. Diantara anak kosnya ialah Soekarno-Bung Karno, Presiden pertama RI-Ketika ia duduk di HBS. ${ }^{5}$

${ }^{3}$ Valina Singka Subekti, Partai Syarikat Islam Indonesia, Kontestasi Politik bingga Konflike Kekuasaan Elite. (Jakarta: Pustaka Obor Indonesia, 2014), 23.

4 Herry Mohammad,Dkk. Tokoh-Tokoh Islam yang Berpengaruh Abad-20.Cet-1. (Jakarta:Gema Insan Press,2006), 28

${ }^{5}$ Ibid., 29 
Pada tahun 1907 sampai 1912, Tjokro mendapat pekerjaan di pabrik gula. Disela sela waktunya, Tjokro juga menulis artikel di Bintang Surabaya. Selepas tahun 1912, Tjokro pindah bekerja ke perusahaan yang bergerak dibidang konsultasi teknik. Belum setahun bekerja disana, datang utusan dari Sarekat Dagang Islam (SDI) Surakarta. Tjokro diminta untuk bergabung dengan SDI. Karena Tjokro masih terlibat kontrak di perusahaan itu, maka pengurus SDI menebusnya dengan sejumlah uang.

SDI merupakan organisasi pertama yang lahir di Indonesia. Organisasi ini didirikan oleh Haji Samanhudi di Surakarta pada 16 Oktober 1905, dengan maksud untuk menentang masuknya pedagang asing yang ingin menguasai ekonomi rakyat. ${ }^{6}$ Samanhoeddhi adalah seorang pedagang yang cukup sukses dan di usia muda ia sudah mendapat gelar Haji. Keberadaan SDI bukan hanya mengurusi soal-soal dagang saja tapi juga politik dan dakwah. Ia menyadari bahwa kader yang bisa membawa kearah cita-cita tersebut tidaklah banyak, belum lagi soal keberanian.

Menghadapi masalah ini Haji.Samanhudi mencari jalan keluar dengan menemui anggota SDI lokal di Surabaya, disana Samanhudi bertemu dengan H.O.S Tjokromaninoto yang merupkapan tokoh terkenal sebagai yang cakap dan bijak, semua kata-katanya mampu mengikat anggotanya. ${ }^{7}$

Perawakan H.O.S Tjokroaminoto telah digambarkan oleh Hamka sebagai berikut: beliau berbadan sedikit kurus, tetapi matanya bersinar kumisnya melentik keatas badannya tegak dan sikapnya penuh keagungan, walaupun beliau sudah tidak menghiraukan lagi gelar Raden Mas yang terdapat didepan namanya, orang masih menganggap bahwa beliau masih mempunyai kharisma yang tinggi, sehingga hampir setiap orang hormat dan kagum kepadanya. Seorang Indo-Belanda melukiskan bahwa Tjokroaminoto perawakannya mengagumkan suka kerja keras dan tidak mengenal lelah, mempunyai suara indah dan hebat, mudah didengar oleh beribu-ribu orang, hampir setiap orang terpaku bila mendengar pidatonya yang lancar dan penuh keyakinan. ${ }^{8}$

Ia merupakan tokoh Sarekat Islam yang didirikan 11 November 1911 hasil modifikasi SDI. ${ }^{9}$ Ia merupakan sosok yang karismatik, ditangan Tjokroamino SDI akhirnya diubah namanya menjadi Sarekat Islam (SI) pada 10 September 1912 dengan haluan SI adalah kumpulan umat Islam yang hendak menegakkkan Islam sebagai agama dan mengilmu Islam. Sehingga anggotanya tidak lagi dibatasi

6 Delian Noer. Gerakan Moderen Islam di Indonesia.( Indonesia: PT.Pustaka LP3ES.1973) 115

7 Suhartono. Sejarah Pergerakan Budi Utomo sampai Proklamasi 1908-1945. (Jakarta: Pustaka Pelajar,1994) 33

8 Anhar Gonggong, H.O.S Tjokroaminoto (Jakarta: Departemen Pendidikan dan Kebudayaan,1985), 1.

9 Akhmad Taufik,Et.al. Sejarah Pemikiran dan Tokoh Modernisme Islam. (Jakarta: Raja Grafindo Persada,2005), 136 
hanya pedagang, tapi dari seluruh atau semua unsur masyarakat. ${ }^{10}$ Tjokroaminoto yang seorang aktivis yang mengilhami banyak pejuang di tanah air membentuk organisasi yang keilmuan. Akhirnya menghadap ilahi pada 17 Desember 1934 di Yogyakarta.

\section{Karya-karya Haji Oemar Said Tjokroaminoto}

Diantara karya intelektual Tjokroaminoto, baik yang berupa buku maupun dalam bentuk lainnya adalah sebagai berikut:

a) Tarikh Agama Islam (1963). Buku ini diterbitkan oleh penggalian dan penghimpunan Sejarah Revolusi Indonesia, Jakarta, 1963. Buku ini ditulis berdasarkan literatur diantaranya: The Spirit Of Islam, karya Amir Ali, dan The Ideal of Prophet.

b) Islam dan Sosialisme (1924). Buku ini merupakan Magnum Opus Tjokroaminoto, yang ditulis di Mataram pada bulan November 1924, dan diterbitkan oleh penerbit Bulan Bintang Jakarta.

c) Reglament Umum Bagi Umat Islam (1934). Karya ini selesai ditulis pada tanggal 4 Februari 1934, dan disahkan oleh kongres PSII di Banjarnegara pada tanggal 20-26 Mei 1934 yang mengupas tenang Akhlaq, Aqidah, Perkawinan, Ekonomi, Amar Ma'ruf Nabiy Munkar serta perjuangan. ${ }^{11}$

d) Kultur dan Adat Islam tabun (1933)

e) Tafsir program dan Azaz Tandim (1965)

f) Al Islam (1916). Majalah ini diterbitkan oleh Sarekat Islam pusat di Solo yang dipimpin oleh Tjokroaminoto, majalah ini umumnya menerbitkan tulisan-tulisan mengenai keagamaan.

g) Bendera Islam (1924-1927). Majalah dua mingguan yang diterbitkan oleh tokoh-tokoh utama Muhammadiyah dan Sarekat Islam di Yogyakarta. Dipimpin oleh Tjokroaminoto, majalah ini bertujuan untuk mempertahankan bangsa dan tanah air berdasarkan agama Islam.

h) Bintang Islam (1923-1926). Majalah dua mingguan ini diterbitkan oleh tokoh utama Muhammadiyah dan Sarekat Islam yang dipimpin oleh Tjokroaminoto, isinya membahas peristiwa-peristiwa di dalam dan di luar negeri yang perlu diperhatikan oleh kaum Muslimin di Indonesia.

i) Fadjar Asia (1927-1930). Majalah berita ini diterbitkan oleh tokoh Sarekat Islam yang dipimpin oleh Tjokroaminoto yang berisi mengenai pandangan- pandangan partai Sarekat Islam.

10 Herry Mohammad,Dkk. Tokoh-Tokoh Islam yang Berpengaruh Abad-20.Cet-1. (Jakarta:Gema Insan Press,2006) hal.30

11 Poin a,b, dan c lihat: M. Masyhur Amin, H.O.S Tjokroaminoto, Rekonstruksi Pemikiran dan Perjuangannya, (Yogyakarta : Cokroaminoto Universty Press, 1995), hal. 3536. 
j) Oetoesan Belanda. Ini adalah Koran harian Islam diterbitkan oleh Tjokroaminoto yang bertujuan untuk mengembangkan aspirasi anggota Sarekat Islam. ${ }^{12}$

\section{1) Terjun ke Dunia Pergerakan Sebagai Pemimpin Sarekat Islam} (SI)

Ditangan Tjokroaminoto SDI diubah namanya menjadi Sarekat Islam (SI) pada 10 september 1912. Dengan haluan SI adalah kumpulan umat islam yang hendak menegakkan pergerakan islam sebagai Agama dan mengilmu Islam. sehingga manggotanya tidak dibatasi hanya pedagang atau Priyai saja, melainkan dari segala unsur masyarakat. ${ }^{13}$

setelah namanya diubah menjadi Sarekat Islam (SI) tujuannya berubah pula menjadi:

- Menyusun masyarakat Islam

- Menggerakkan hati umat Islam untuk bersatu di dalam lingkungan dan batas undang-undang Negara, melakukan segala upaya untuk menggangkat derajat rakyat, guna mensentosakan dan memakmurkan tumpah darah. ${ }^{14}$

H.O.S.tjokroaminoto yang merupakan tokoh Sarekat Islam memiliki karisma kepemimpinan yang luar biasa, walaupun pengetahuannya tetang keIslamannya hasil pengetahuan nya sendiri. Namun, melalui organsisasi SI yang dipimpinnya, telah menarik banyak simpati kalangan intelektual pada saat itu, termasuk diantaranya adalah H.Agus Salim san Abdoel Moeis. ${ }^{15}$

Sehingga pada masa ini disimpulkan Sarekat Islam yang didirikan di Surakarta pada tahun 1912, semula bernama Sarekat Dagang Islam dan berpusat di Kota Surakarta merupakan organisasi pergerakan yang bersifat nasional dan modern (untuk ukuran bangsa bumiputera pada waktu itu) melakukan berbagai perubahan. Pertama, mitos seperti Ratu Adil sebagai paham yang bersifat mistis religius, beralih pada kesadaran ideologis dengan ideologi yang bersifat rasional dan realistis.

Alasan ini Karena pada dasarnya para pemimipin Sarekat Islam seperti Cokroaminoto, Agus Salim dan Abdoel Moeis adalah orangorang yang rasional. Kedua, mistis religius yang bersi-fat lokal, pada citacita yang mengandalkan kharisma seorang pemimpin den-gan pola gerakan tertutup, beralih pada kekuatan organisasi yang bersifat terbuka.

12 Poin d sampai 1, lihat: Deliar Noer, Gerakan Politik. Modern Islam di Indonesia tabun 1900-1942, (Indonesia: PT.Pustaka LP3ES,1973), 25-26.

${ }^{13}$ Herry Mohammad,Dkk, Tokoh-Tokoh Islam yang Berpengaruh Abad 20 Cet-1.(Jakarta: Gema Insan Press.2006), .30.

${ }^{14}$ Amelz, H.O.S.Tjokroaminoto dan Perjuangannya Jilid I.(Jakarta:Bulan Bintang,1951) 106-107.

${ }^{15}$ Akhmad Taufik. Et.al, Sejarah Pemikiran dan Tokob Modernisme Islam. (Jakarta: Raja Grafindo Persada,2005),134. 
Ketiga, pusat pergerakan yang semula berpusat di desa-desa beralih ke Kota. Sejak awal abad 20, bersamaaan dengan terjadinya perubahan sosial, Kota-Kota di Indonesia telah memainkan peranan dalam berbagai bidang termasuk dalam gerakan politik melawan kolonial yang dipelopori oleh kaum terpelajar dan kelas menengah (kaum priyayi atau pamong praja, pedagang, karyawan jurnalis dan pegawai pemerintah). ${ }^{16}$

Perkembangan SI semakin membesar dan membahayakan bagi pemerintahan Belanda. Sampai masa tertentu SI pusat tidak diakui membawahi cabang-cabang di daerah. Pada 18 Februari 1914 mereka memutuskan membuat pengurus pusat. Walaupun demikian Tjokroaminoto tidak kehilangan akal, ia pun kemudian membentuk Central Sarekat Islam (CSI) pada Februari 1915 dan menjadikan seluruh anggota dari cabang-cabang harus tanduk kepada CSI Pusat. ${ }^{17}$ di Surakarta yang dipimpin oleh Samanhudi, Tjokroaminoto, Raden Gunawan, Abdul Muis dll. ${ }^{18}$

Dengan taktik yang dilakukannya ini, akhirnya pemerintah belanda memberikan pengakuan terhadap keberadaan SI Pusat Tanggal 18 Maret 1916 CSI diakui pemerintah. ${ }^{19}$ Dengan timbulnya pengakuan dari pihak pemerintah belanda ini, pendukung-pendukung SI pun bertebaran dan semakin intensif mengadakan pertemuan-pertemuan politik. ${ }^{20}$

Central Sarekat Islam (CSI) melakukan kongres pertamanya pada 1913 di surabaya,yang dinamai Kongres Nasional Sarekat Islam. istilah Nasional digunakan untuk menjelaskan bahwa Sarekat Islam mencita-citakan adanya satu nasional bagi penduduk asli Indonesia. Dengan demikian gerakan sarekat Islam lebih meningkat kearah memeprsatukan bangsa idnonesia sebagai satu bangsa. ${ }^{21}$

Sarekat Islam yang harusnya disahkan di tahun 1917,22 Tapi Tjokroaminoto membawanya lebih awal aktifitas politik pada Kongres Nasional di bandung 1916. Kongres ini bercirikan massa dan nasional.

Dengan adanya kesatuan dan kekuatan dari seluruh organisasi SI, maka gerakan politiknya pun semakin berani dan radikal. Pada kongres di Batavia (1917) SI mengaklamasi tuntutan kemerdekaan ke

${ }^{16}$ Nurhadiantomo. Hukum Reintegrasi Sosial: Konflik-Konflik Sosial PriNonpri dan Badan Keadilan Sosial. (Surakarta: Muhammadiyah University Press, 2004), 82.

17 M.M.Amin, H.O.S.Tjokroaminoto: Rekonstruksi Pemikiran dan Perjuangannya. (Yogyakarta :Cokroaminoto University Press,1995), 72.

${ }^{18}$ Boechori Tamam.Sejarah Perang di Indonesia.(Medan:Bakti), 27.

19 Delian Noer, Gerakan Moderen Islam di Indonesia.(Indonesia: PT.Pustaka LP3ES,1973), 119.

20 Muhammad Abdul Gani, Cita Dasar dan Pola Perjuangan Syarikat Islam.(Jakarta:Bulan Bintang,1984), 211.

21 Kansil dan Julianto, Sejarah Perjuangan Pergerakan Kebangsaan Indonesia. (Jakarta:Erlangga,1988), 26.

${ }^{22}$ Taufik Abdullah,Et.al. Sejarah Ummat Islam Indonesia.(Jakarta:MUI,1991), 230. 
pemerintah belanda, sehingga pemerintah Belanda memberikan antisipasi dan rintangan yang serius kepada SI yaitu dengan jalan memasukan ideology Marxisme (Komunis) ke Indonesia untuk infiltrasi terhadap SI. ${ }^{23}$ Adapun faktor-faktor yang mempermudah infiltrasi ISDV ke dalam tubuh SI antar lain:

1. Centraal Sarekat Islam (CSI) sebagai badan koordinasi pusat memiliki kekuasaan yang lemah. karenakan tiap cabang SI bertindak sendiri-sendiri.

2. Peraturan partai pada waktu itu memperbolehkan keanggotaan multipartai.

3. Akibat dari Perang Dunia I, membumbungnya harga-harga dan menurunnya upah karyawan perkebunan untuk mengimbangi kas pemerintah kolonial mengakibatkan dengan mudahnya rakyat memihak pada ISDV.

4. Akibat kemiskinan yang semakin diderita rakyat semenjak Politik Pintu Terbuka (sistem liberal) dilaksanakan pemerintah kolonialis sejak tahun 1870 dan wabah pes yang melanda pada tahun 1917 di Semarang. ${ }^{24}$

5. Kehidupan rakyat yang miskin akibat sistem sewa tanah yang di berlakukan pemerintah, kekurangan bahan makanan karena harga beras sangat mahal dan tidak terjangkau rakyat kecil serta sanitasi lingkungan tempat tinggal yang kumuh dan tidak sehat menyebabkan masyarakat diserang berbagai penyakit, antara lain wabah kolera tahun 1906, influensa tahun 1908, typhus, pes dan malaria yang membunuh $25 \%$ pen-duduk Semarang, sehingga angka kematian lebih besar daripada angka kelahiran. ${ }^{25}$

Adapun tokoh-tokoh yang melakukan itu diantaranya H.J.K.Sneevliet yang pada tahun 1914 mendirikan Indiche Sociaal Democratische vereenigning (ISDV), organisasi Sosial Demokrasi Hindia Belanda. ${ }^{26}$ mereka menggunakan taktik infiltrasi yang dikenal sebagai "Blok di dalam", mereka berhasil menyusup ke dalam tubuh SI dengan tujuan membela rakyat kecil dan menentang kapitalisme namun dengan

${ }^{23}$ Hasan Mustapa, M.Si, Pemikiran Politik Islam Sjafruddin Prawinegara (1911-1989) Good Governance, Civil Society dan Islam Transformatif. (Jawa Barat:Nusa Litera Inspirasi,2017) ,301.

${ }^{24}$ Akhmad Taufik.Et.al. Sejarah Pemikiran dan Tokob Modernisme Islam. (Jakarta: Raja Grafindo Persada, 2005), 138-139.

25 Sulistiyono, Arif Gunawan. "Fajar Merah Di Ufuk Semarang”. Dalam Hayamwuruk. No. 2. Th. XIV, 2004), 27.

${ }^{26}$ Hasan Mustapa,M.Si, Pemikiran Politik. Islam Sjafruddin Prawinegara (1911-1989) Good Governance, Civil Society dan Islam Transformatif. (Jawa Barat:Nusa Litera Inspirasi,2017), 212. 
cara yang berbeda. ${ }^{27}$ Akhirnya mereka berhasil memengaruhi tokohtokoh muda SI seperti Semaoen, Darsono, Tan Malaka, dan Alimin Prawirodirdjo. Hal ini menyebabkan SI pecah.

Akibat peristiwa tersebut Sarekat Islam pecah menjadi 2 aliran, yaitu: (1) Sarekat Islam Merah (SI Merah) yang dipimpin Semaoen yang berasaskan sosial-komunis dan berpusat di Semarang dan (2) Sarekat Islam Putih (SI Putih) yang dipimpin Agus Salaim yang berasaskan kebangsaan dan keaga-maan dan berpusat di Yogyakarta. ${ }^{28}$

SI Putih (H. Agus Salim, Abdul Muis, Suryopranoto, Sekarmadji Maridjan Kartosoewirjo) berhaluan kanan berpusat di kota Yogyakarta. Sedangkan SI Merah (Semaoen, Alimin, Darsono) berhaluan kiri berpusat di kota Semarang. Sedangkan HOS Tjokroaminoto pada mulanya adalah penengah di antara kedua kubu tersebut. ${ }^{29}$

Jurang antara SI Merah dan SI Putih semakin melebar saat keluarnya pernyataan Komintern (Partai Komunis Internasional) yang menentang cita-cita Pan-Islamisme. Pada saat kongres SI Maret 1921 di Yogyakarta, H. Fachruddin, Wakil Ketua Muhammadiyah mengedarkan brosur yang menyatakan bahwa Pan-Islamisme tidak akan tercapai bila tetap bekerja sama dengan komunis karena keduanya memang bertentangan. Di samping itu Agus Salim mengecam SI Semarang yang mendukung PKI. Darsono membalas kecaman tersebut dengan mengecam beleid (Belanda: kebijaksanaan) keuangan Tjokroaminoto. SI Semarang juga menentang pencampuran agama dan politik dalam SI. Oleh karena itu, Tjokroaminoto lebih condong ke SI haluan kanan (SI Putih)..$^{30}$

SI mengaklamasi tuntutan kemerdekaan ke pemerintah belanda, sehingga pemerintah Belanda memberikan antisipasi dan rintangan yang serius kepada SI yaitu dengan jalan memasukan ideology Marxisme (Komunis) ke Indonesia untuk infiltrasi terhadap SI oleh Sneevliet. ${ }^{31}$ Komunis inilah yang nantinya manjadi perintang terhadap perjuangan murni SI, karena di dalam batang tubuh SI banyak dimaksukan tokohtokoh yang berhaluan komunis seperti Semaun, Alimin dan lainnya. Sehingga SI pun menjadi lemah.

27 Musyrifah Sunanto, Sejarah Peradaban Islam Indonesia. (Jakarta: Rajawali Pers, 2012) , 137.

28 Suhartono. Sejarah Pergerak Na-sional: Dari Budi Utomo Sampai Proklamasi 19081945. (Yogyakarta: Pustaka Pelajar, 1994), 37.

29 Delian Noer, Gerakan Modern Islam di Indonesia 1900-1942. (Jakarta: Pustaka LP3ES, 1996), 139.

30 Delian Noer, Gerakan Modern Islam di Indonesia 1900-1942. (Jakarta: Pustaka LP3ES, 1996), 140.

31 Hasan Mustapa,M.Si, Pemikiran Politik. Islam Sjafruddin Prawinegara (1911-1989) Good Governance, Civil Society dan Islam Transformatif. (Jawa Barat:Nusa Litera Inspirasi,2017) , 301. 
Pembelaan yang dilakukan Tjokroaminoto dan Agus Salim terhadap keberadaan SI yang tercemar oleh sifat komunise pun tidak dapat mengembalikan citra SI. Sehingga SI pun banyak ditinggalkan oleh anggota-anggotanya, begitu juga orang-orang yang berhaluan di SI banyak yang keluar dan resmi bergerak di bawah panji komuniksme tulen. ${ }^{32}$

Dampak perpecahan tersebut tampak telah meningkatkan rasa permusuhan di kedua belah pihak. Persaingan antar cabang-cabang Sarekat Islam dan cabang-cabang Sarekat Rakyat telah menyeret PKI ke dalam lingkungan yang keras dan semakin radikal atau anarki. Akhirnya PKI tergelincir dalam sebuah pemberontakan kepada organisasi ini tidak dapat memutuskan apakah harus membubarkan Sarekat Rakyat yang jumlah pengikutnya dari kelas proletar semakin bertambah banyak. Suasana yang tidak menguntung-kan bagi pergerakan nasional berlansung lama dan berlarut-larut. Gerakan kiri terjebak ke dalam kondisi yang tidak mengutungkan, lebih-lebih setelah Semaoen mengalami nasib yang tragis yaitu di buang oleh pemerintah kolonial Belanda karena menyerukan pemogokan buruh pada tahun 1923.33

Pecahnya SI terjadi setelah Semaoen dan Darsono dikeluarkan dari organisasi. Hal ini ada kaitannya dengan desakan Abdul Muis dan Agus Salim pada kongres SI yang keenam 6-10 Oktober 1921 tentang perlunya disiplin partai yang melarang keanggotaan rangkap. Anggota SI harus memilih antara SI atau organisasi lain, dengan tujuan agar SI bersih dari unsur-unsur komunis.

Pada tahun 1920 Sarekat Islam mengeluarkan peraturan disiplin partai, dimana anggota dari suatu perkumpulan atau partai lain tidak boleh merangkap menjadi anggota Sarekat Islam. Untuk anggotra Sarekat Islam ini berarti mereka harus memilih antara keanggotaan Sarekat Islam atau mereka keluar dari Sarekat Islam. ${ }^{34}$ Keputusan mengenai disiplin partai diperkuat lagi dalam kongres SI pada bulan Februari 1923 di Madiun. Dalam kongres Tjokroaminoto memusatkan tentang peningkatan pendidikan kader SI dalam memperkuat organisasi dan merupah CSI menjadi PSI. ${ }^{35}$

32 Hasan Mustapa,M.Si, Pemikiran Politik. Islam Sjafruddin Prawinegara (1911-1989) Good Governance, Civil Society dan Islam Transformatif. (Jawa Barat:Nusa Litera Inspirasi,2017) .301 .

33 Priyono. "Komunisme Dalam Sarekat Islam Cabang Se-marang Tabun 1916-1920". (Semarang: Fakultas Sastra UNDIP,1990), 4.

34 Deliar Noer. Gerakan Modern Islam di Indonesia Tabun 1900-1942.(Jakarta : LP3ES,1996), 138.

35 K.H.Firdaus.A.N. Syarikat Islam Bukan Budi Utomo.(Jakarta:CV.Datayasa.1997), 23. 
Pada kongres PSI tahun 1929 menyatakan bahwa tujuan perjuangan adalah mencapai kemedekaan nasional. Karena tujuannya yang jelas itulah PSI ditambah namanya dengan Indonesia sehingga menjadi Partai Sarekat Islam Indonesia (PSII). Perubahan nama PSII ini diusulkan karena visi misi yang lebih nasional atau lebih menyeluruh ke penduduk asli Indonesia. Sekali lagi perubahan nama ini lagi lagi untuk mengikuti perubahan iklim politik yang menjadi alasan dibalik perubahan nama partai.

Pada tahun itu juga PSII menggabungkan diri dengan Permufakatan Perhimpunan-Perhimpunan Politik Kebangsaan Indonesia (PPPKI) yang didirikan oleh Seokarno pada tahun 1927.36 Ternyata penggabungan tersebut tidak memberikan kesempatan baik untuk maju bagi PSII. Sehingga PSII tidak kerasan bergabung dengan PPPKI dan mengudurkan diri pada 28 Desember 1930.

Sehingga pada 1973 (PSII) dan pada Majlis Tahkim (kongres nasional) ke-35 di Garut tahun 2003 mengganti namanya menjadi Syarikat Islam (disingkat SI). Sejak kongres tersebut eksistensi dan pergerakan Syarikat Islam yang masih ada dan tetap bertahan hingga sekarang disebut Syarikat Islam. ${ }^{37}$

\section{2) Tafsir Asas}

Pada 16 Oktober 1931, sebuah buku kecil terbit dengan judul Tafsir Program-Asas dan Program-Tandhim yang diulis oleh Tjokro selaku Presiden Dewan Partai Sarekat Islam Indonesia (PSII). Didalamnya berisi tentang arah dan gerak perlawanan partai, antara lain bersandarkan pada kebersihan tauhid, bersandar kepada ilmu dan bersandarkan kepada siyasah (politik) yang berkaitan dengan bangsa, tumpah darah dan menyatukan negeri-negeri berpenduduk muslim (Pan Islamisme). Semangat Pan Islamisme yang diusung oleh Jamaluddin alAfghani dari Timur tengah itu merebak ke India dan Indonesia. Dalam pendahuluannya, Tjokro menulis:

Pergerakan kita yang mula-mula bernama sarekat islam atau harus ditulis Sjarekat Islam, kemudian diganti dengan nama Partai Sjarekat Islam IndiaTimur pada tahun 1927, dan akhirnya pada tahun 1930 diganti lagi dengan nama Partai Sjarekat Islam Indonesia sesunggubnya Nampak betuk sifat sifat, maksud dan tujuannya ialah ketika sudah ditetapkan program-Asasnja (Beginsel-Program) yang pertama-tama dan program-Pekerjaanya (Program van Actie) didalam kongresnya pada tahun 1917 di kota Jakarta (Betawi), yang kemudian Program Asas daan Program Pekerjaan itu diubah di dalam kongres di kota Mataram (Yogyakarta) pada tabun 1920 dan akbirnya

${ }^{36}$ Slamet Muljiana, Kesadaran Nasional: dari Konolialisme sampai Kemerdekaan Jilid I. (Yogyakarta:LKIS, 2008), 133.

${ }^{37}$ Slamet Muljiana, Kesadaran Nasional: dari Konolialisme sampai Kemerdekaan Jilid I. (Yogyakarta:LKIS, 2008), 133. 
diubah lagi pada kongres di Mataram pada 1930, dimana program Asas itu ditambah dalam dan luas pemahamannya dan program pekerjaan yang biasanya banya berlaku beberapa tabun saja lamanya, diganti dengan program perlawanan yang kekuatannya hamper sama sebagai Program Asas....

Pergerakan kita Partai Sjarekat Islam Indonesia yang maksud nya dikatakan dengan singkat: akan menjalankan islam dengan seluas-luasnya dan sepenubpenubnya, supaya kita bisa mendapatkan suatu Dunia Islam yag sejati dan bisa mnuntut kehidupan Muslim yang seseunggubnya. Nyatanya perlu sekali memiliki suatu program Asas dan suatu program tandhim, yang arus menjadi dasar dan pedoman cita-cita yanga kita tuu dan bagi segala perbuatan yang untuk mencapai maksud itu.

Sesunggubnya pun Islam itu agama Allah dan ialah peraturan-peratauran yang sempurna yang diberikan oleh Allah Ta'ala kepada manusia untuk mencapai keselamatan di dunia dan di akhirat, harusnyalah kita ingat bahwa manusia itulah yang membikin riwayatnya sendiri. Oleh karena itu, maka dalam usaha kita menuju kehidupan muslim yang sesungguh-sunggubnya itu haruslah mengetahui sifat dan keadaan keadaan pergaulan hidup manusia, yang kita hidup di kehdupan yang sekarang ini dan dengan sejelas-jelasnya kita tahus mengetahui kecelaan dan kebusukan-kebusukannya, yang harus lenyap dan mesti dilenyapkan. Karena mnejadi sebabnya tidak bisa ada kehidupan Muslim yang sesunggub-sungguhnya sebagai yang kita harapkan ataupun sedikitnya menjadi rintangan bagi usaha kita akan mencapai kehiduan muslim demikian itu. ${ }^{38}$

Dari kutiapan di atas tampak jelas apa yang dicita-citakan oleh Tjokro dengan partai yang dibesarkannya itu. Itu pula sebabnya, mengapa ia mengubah namanya dari SDI menjadi Partai Sjarekat Islam Indonesia. Islam sebagai jalan hidup adalah pilihan yang terus diperjuangkan oleh Tjokro.

Sebagai seorang aktvis yang mengilhami banyak pejuang di tanah air, Tjokro juga berkiprah dan mnedorong terbentuknya organisasi-organisasi yang bersifat keilmuan. Ia, diantara lain mendorong didirakannya Indonesische Studie Club (ISC) yang dirikan oleh Dr.Soetomo pada juli 1924 di Surabaya. Setahun kemudian, bersama Haji Agus Salim, membidani Jong Islamieten Bond (JIB) yang merupakan himpunan para mahasiswa dan pelajar islam agar tak lalai dengan agamanya. JIB inilah yang merupakan cikal bakal lahirnya para cendikiawan muslim di Indonesia.

\section{Kesimpulan}

Raden Mas Haji Oemar Said Tjokroaminoto atau dikenal dengan H.O.S Tjokroaminoto merupa- kan salah satu tokoh pergerakan nasional yang

38 Herry Mohammad,Dkk. Tokoh-Tokoh Islam yang Berpengaruh Abad-20.Cet-1. (Jakarta:Gema Insan Press,2006), 31-33. 
memberikan pengaruh untuk memperjuangkan kesejahteraansosial dan juga berpengaruh besar dalam dinamika politik Indonesia, termasuk di dalamnya membentuk pemikiran politik maupun mempengaruhi tindakan politik banyak tokoh pergerakan nasional.

Ia merupakan tokoh Sarekat Islam yang didirikan 11 November 1911 hasil modifikasi SDI. Ia merupakan sosok yang karismatik, ditangan Tjokroamino SDI akhirnya diubah namanya menjadi Sarekat Islam (SI) pada 10 September 1912 dengan haluan SI adalah kumpulan umat Islam yang hendak menegakkkan Islam sebagai agama dan mengilmu Islam, sampai mengalami perubahan nama menjadi PSII.

Dalam pergerakan dakwah nya dalam gerak perlawanan partai, antara lain bersandarkan pada kebersihan tauhid, bersandar kepada ilmu dan bersandarkan kepada siyasah (politik) yang berkaitan dengan bangsa, tumpah darah dan menyatukan negeri-negeri berpenduduk muslim (Pan Islamisme).

\section{Daftar Pustaka}

Gonggong, Anhar. (1985) H.O.S. Tjokroaminoto. Jakarta: Departemen Pendidikan dan Kebudayaan

Adams, Cindy. (1966) Bung Karno, Penyambung Lidah Rakyat Indonesia. Jakarta: Gunung Agung

Subekti, Valina Singka. (2014) Partai Syarikat Islam Indonesia, Kontestasi Politik hingga Konflik Kekuasaan Elite. Jakarta: Pustaka Obor Indonesia.

Herry Mohammad, (2006) Tokoh-Tokoh Islam yang Berpengaruh Abad-20.Cet1. Jakarta: Gema Insan Press.

Noer,Delian.(1973) Gerakan Moderen Islam di Indonesia. Indonesia: PT.Pustaka LP3ES

Suhartono.(1994) Sejarah Pergerakan Budi Utomo sampai Proklamasi 1908-1945. Jakarta: Pustaka Pelajar.

Taufik, Akhmad. (2005) Sejarah Pemikiran dan Tokoh Modernisme Islam. Jakarta: Raja Grafindo Persada

Amin, M. Masyhur. (1995) H.O.S Tjokroaminoto, Rekonstruksi Pemikiran dan Perjuangannya. Yogyakarta : Cokroaminoto Universty Press.

Amelz. (1951) H.O.S.Tjokroaminoto dan Perjuangannya Jilid I. Jakarta: Bulan Bintang. 
Nurhadiantomo. (2004) Hukum Reintegrasi Sosial: Konflik-Konflik Sosial PriNonpri dan Badan Keadilan Sosial. Surakarta: Muhammadiyah University Press.

Amin, M.M.(1995) H.O.S.Tjokroaminoto: Rekonstruksi Pemikiran dan Perjuangannya. Yogyakarta :Cokroaminoto University Press.

Tamam,Boechori. Sejarah Perang di Indonesia.Medan:Bakti.

Gani,Muhammad Abdul. (1984) Cita Dasar dan Pola Perjuangan Syarikat Islam.Jakarta:Bulan Bintang.

Kansil dan Julianto. (1988) Sejarah Perjuangan Pergerakan Kebangsaan Indonesia. Jakarta: Erlangga.

Abdullah, Taufik.Et.al.(1991) Sejarah Ummat Islam Indonesia. Jakarta: MUI,1991.

Mustapa, Hasan. (2017) Pemikiran Politik Islam Sjafruddin Prawinegara (19111989) Good Governance, Civil Society dan Islam Transformatif. Jawa Barat: Nusa Litera Inspirasi.

Sulistiyono, Arif Gunawan.( 2004 )“Fajar Merah Di Ufuk Semarang”. Dalam Hayamwuruk. No. 2. Th. XIV.

Sunanto,Musyrifah.(2012) Sejarah Peradaban Islam Indonesia. Jakarta: Rajawali Pers.

Suhartono. (1994) Sejarah Pergerak Na-sional: Dari Budi Utomo Sampai Proklamasi 1908-1945. Yogyakarta: Pustaka Pelajar.

Priyono.(1990) “Komunisme Dalam Sarekat Islam Cabang Se-marang Tahun 1916-1920”. Semarang: Fakultas Sastra UNDIP.

K.H.Firdaus.A.N.( 1997) Syarikat Islam Bukan Budi Utomo. Jakarta:CV.Datayasa.

Muljiana, Slamet.(2008) Kesadaran Nasional: dari Konolialisme sampai Kemerdekaan Jilid I. Yogyakarta: LKIS. 